УДК 614.841 .3

\title{
СИСТЕМАТИЗАЦІЯ ПРОЦЕСУ УПРАВЛІННЯ ПОЖЕЖНОЮ БЕЗПЕКОЮ ОБ'ЄКТА ЗАХИСТУ
}

О.О. Сізіков, канд. техн. наук, ст. наук. співр., В.В. Ніжник, канд. техн. наук, ст. наук. співр., Я.В. Балло*, канд. техн. наук, С.Ю. Голікова, О.В. Савченко

Український науково-дослідний інститут иивільного захисту, Україна

\section{ІНФОРМАЦІЯ ПРО СТАТТЮ}

Надійшла до редакції: 23.10.2019

Пройшла рецензування: 09.12.2019

\section{КЛЮЧОВІ СЛОВА:}

система управління пожежною безпекою об'єкта, організаційноуправлінські заходи, суб'єкт управління пожежною безпекою об'єкта захисту, об'єкт управління, організаційна структура, алгоритм управління \begin{abstract}
АНОТАЦІЯ
Наведені результати досліджень щодо обґрунтування загальних положень системи управління пожежною безпекою об'єкта захисту. Вперше встановлено низку термінів та визначень понять, які характеризують та конкретизують окремі елементи системи управління пожежною безпекою об'єкта. Показано недосконалість існуючих підходів щодо наявних організаційних заходів забезпечення пожежної безпеки на об'єкті захисту. Наведено вітчизняний та зарубіжний досвід щодо ефективної реалізації управлінського впливу за допомогою управлінських рішень суб'єктів управління об'єкта захисту, що дозволяє реалізовувати на об'єктах різного функціонального призначення організаційні вимоги та технічні вимоги до системи запобігання пожежі та комплексу протипожежного захисту. В результаті проведених досліджень розроблено організаційну структуру системи управління пожежною безпекою об'єкта та встановлені вимоги щодо ії функціонування та алгоритму управління.
\end{abstract}

Bcmyn. Важко не погодитись 3 авторами публікації [1], які стверджують, що поняття «пожежна безпека» (далі - ПБ) об'єкта має не лише технічний зміст (тобто, що це не тільки сукупність протипожежних інженернотехнічних, будівельно-архітектурних та організаційно-технічних заходів та засобів), але й певний «організаційно-управлінський зміст» iз забезпечення ПБ об'єкта, який передбачає відповідні організаційно-управлінські заходи. Технічні протипожежні заходи реалізуються на об'єкті у тому числі завдяки управлінській діяльності осіб, які є суб'єктами управління ПБ об'єкта.

Згідно [2] перелік організаційно-технічних заходів із забезпечення ПБ об'єкта захисту, наведений в основоположному стандарті [3], є обмеженим, а вимоги щодо формування організаційної структури для забезпечення управління ПБ об'єкта та іiі функціонування взагалі відсутні.

Тому на основі проведених досліджень [4] розроблено національний стандарт [5], який удосконалює у цілому систему забезпечення ПБ об'єктів, зокрема тим, що на об'єкті, окрім системи запобігання пожежі та комплексу протипожежного захисту (у минулому системи протипожежного захисту), необхідно передбачити систему управління ПБ об'єкта, що відповідає європейським підходам.

Стандарт [5] вперше в Україні на рівні державної стандартизації вводить поняття «системи управління пожежною безпекою об'єкта» (далі - СУПБ), яке визначається як: https//doi.org/10.33269/nvcz.2019.2.41-49 сукупність заходів суб'єкта управління пожежною безпекою об'єкта 3 обстеження, аналізу й оцінки стану ПБ об'єкта захисту, прийняття, організації та контролю виконання управлінських рішень для забезпечення ПБ об'єкта захисту.

Важливість та необхідність функції управління різноманітними процесами у різних сферах діяльності підтверджує перелік міжнародних та національних стандартів України, гармонізованих 3 міжнародними нормативними документами, а саме щодо: системи управління якістю [6], системи екологічного управління [7], системи управління безпечністю харчових продуктів [8], системи управління інформаційною безпекою [9], системи управління безпекою дорожнього руху [10], системи контролювання гігієни та керування безпекою праці [11].

Враховуючи те, що національний стандарт [5] містить лише концептуальні вимоги до СУПБ, проведено дослідження щодо обгрунтування загальних положень СУПБ та стандартизовано: терміни та визначення понять стосовно СУПБ; основні завдання СУПБ, іiі організаційна структура; порядок функціонування СУПБ (алгоритм управління); управлінські заходи щодо виконання технічних вимог, передбачених системою запобігання пожежі та забезпечення протипожежного режиму об'єкта захисту; управлінські заходи щодо виконання технічних вимог, передбачених комплексом протипожежного захисту об'єкту захисту. Таким чином, *E-mail: ballo@undicz.dsns.gov.ua 
проблемним питанням залишається недосконалість існуючих підходів щодо наявних організаційних заходів забезпечення пожежної безпеки на об'єкті захисту, чому й присвячена дана робота.

\section{Мета, об'єкт та предмет досліджень.} Метою роботи $\epsilon$ удосконалення протипожежного захисту об'єктів шляхом обгрунтування загальних положень СУПБ, яка завдяки управлінським рішенням суб'єкта управління сприяє досягненню прийнятного рівня ризику виникнення пожежі на об'єкті захисту.

Постановка задач та їх вирішення. Для досягнення поставленої мети необхідно було розв'язати такі задачі:

- провести аналіз статистичних даних про пожежі та їхні наслідки на підприємствах, в організаціях i закладах стосовно виявлення впливу на них невиконання чи відсутності організаційно-управлінських заходів щодо забезпечення пожежної безпеки об'єкта;

- провести аналітичні дослідження впливу державної системи управління пожежною безпекою на СУПБ об'єкта;

- провести аналіз вітчизняної та закордонної законодавчої бази, нормативних та нормативно-правових актів щодо організаційно-управлінської діяльності суб'єктів управління пожежною безпекою об'єкта захисту;

- провести аналіз кваліфікаційних вимог до посадових осіб, відповідальних за забезпечення ПБ об' єкта, а також нормативного забезпечення організації та проведення інструктажів, навчання та перевірки знань 3 питань ПБ осіб, що перебувають на об'єкті захисту;

- провести аналіз законодавчих та нормативно-правових актів щодо класифікації суб'єктів господарювання для опрацювання організаційної структури СУПБ об'єкта захисту;

- обгрунтувати загальні положення СУПБ об'єкта захисту.

За результатами досліджень статистичних даних про пожежі та їхні наслідки на підприємствах, в організаціях і закладах України впродовж 2008-2017 років стосовно виявлення впливу на них невиконання або відсутності організаційно-управлінських заходів щодо забезпечення ПБ, визначені основні порушення, зокрема, пов'язані 3: відсутністю на об'єктах інструкцій щодо порядку поводження 3 пожежно-небезпечними речовинами та матеріалами; організацією на об'єкті протипожежного режиму; забезпеченням нормованої, у порівнянні 3 фактичною, чисельності людей на об'єктах за умовами їх безпеки під час пожежі; організацією порядку зберігання речовин i матеріалів, у залежності від їх фізико-хімічних і пожежонебезпечних властивостей; недостатнім рівнем організації навчань та проведенням інструктажів 3 правил ПБ працівників; низьким рівнем проведення заходів щодо порядку дій на випадок виникнення пожеж та евакуації людей; неефективністю використання протипожежної техніки під час гасіння пожеж; відсутністю паспортизації речовин, матеріалів, виробів, будівель і споруд у частині забезпечення ПБ; низьким рівнем застосування засобів наочної агітації із забезпечення ПБ.

Крім того, на об'єктах можливе порушення норм і правил ПБ, які пов'язані зі здійсненням адміністрацією об'єктів вводу в експлуатацію незастрахованих об'єктів та не повідомлення про свою діяльність органів Державного нагляду (контролю) у сфері пожежної безпеки (далі - ОДН ПБ) й отримання від них дозвільної документації на провадження своєї діяльності, що свідчить про недостатню взаємодію суб'єктів господарювання 3 зовнішніми суб'єктами, які впливають на забезпечення ПБ об'єкта захисту.

Як видно на рисунку 1, найбільший відсоток порушень $(45,8 \%)$ пов'язаний 3 відсутністю управлінських заходів суб'єктів управління ПБ об'єктів, направлених на організацію протипожежного режиму на адміністративних, виробничих i торговельних об'єктах; 25,2\% становлять порушення, пов'язані 3 недостатнім рівнем організації суб'єктами управління ПБ об'єктів навчань та проведенням інструктажів 3 питань ПБ 3 працівниками.

Наведені дані підтверджують недостатній рівень процесу управління станом ПБ об'єктів або відсутність управління цим процесом взагалі, а також недосконалість існуючих організаційно-управлінських заходів суб'єктів управління забезпеченням ПБ об’єктів та необхідність впровадження на об'єктах СУПБ, основними завданнями якої є:

- проведення технічної політики 3 питань пожежної безпеки, яка відповідає сучасному рівню розвитку науки й техніки;

- здійснення організаційно-управлінських заходів для виконання технічних вимог, передбачених системою запобігання пожежі [5] та забезпечення протипожежного режиму об'єкта захисту [12]; 


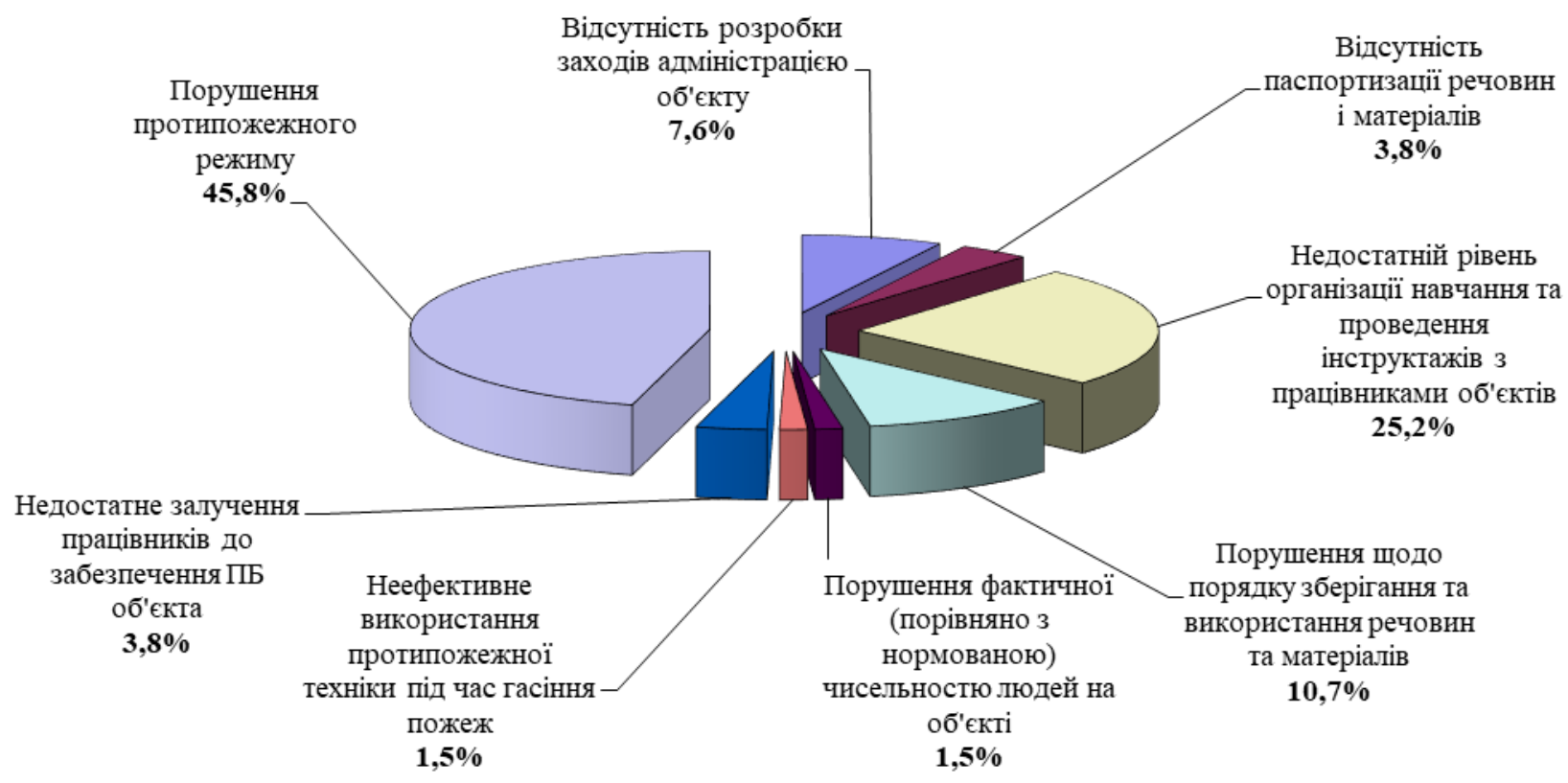

Рисунок 1 - Основні порушення ПБ, обумовлені невиконанням організаційно-управлінських заходів

- здійснення управлінських заходів для виконання технічних вимог, передбачених комплексом протипожежного захисту [5];

- забезпечення своєчасного усунення порушень вимог законодавства та нормативноправових актів у сфері пожежної безпеки згідно з приписами ОДН ПБ;

- матеріально-технічне забезпечення об'єкта захисту протипожежною технікою (системами протипожежного захисту [13], первинними засобами пожежогасіння тощо) та засобами протипожежного захисту (вогнегасними речовинами, вогнезахисними речовинами та матеріалами, вогнеперешкоджальними пристроями тощо);

- забезпечення прийнятого рівня ризику виникнення пожежі на об'єкті та підвищення ймовірності успішного евакуювання людей у разі виникнення пожежі на об'єкті захисту, підвищення ефективності ліквідації пожежі.

У результаті проведеного аналізу вітчизняної та закордонної законодавчої бази, нормативно-правових та нормативних актів щодо організаційно-управлінської діяльності суб'єктів управління ПБ об'єктів захисту встановлені такі терміни та визначення понять:

- суб'єкт управління пожежною безпекою об’єкта захисту - посадові особи органів виконавчої влади, посадові особи органів місцевого самоврядування, відповідальні за пожежну безпеку об'єкта захисту, а також суб'єкти господарювання (власники або керівники цих суб'єктів господарювання, або орендарі об'єкта захисту згідно 3 цивільноправовим договором), посадові особи, призначені відповідальними за пожежну безпеку об'єкта захисту;

- об'єкт управління пожежною безпекою об'єкта захисту - діяльність осіб, які перебувають на об'єкті захисту;

- управлінські заходи щодо забезпечення пожежної безпеки об'єкта захисту - сукупність управлінських заходів, спрямованих на виконання технічних вимог, передбачених системою запобігання пожежі, комплексом протипожежного захисту та забезпечення протипожежного режиму на об'єкті захисту;

- управління пожежною безпекою об'єкта захисту - процес впливу суб'єкта управління пожежною безпекою на діяльність осіб, які перебувають на об'єкті захисту для забезпечення відсутності на цьому об'єкті неприпустимого ризику виникнення та розвитку пожежі;

- оцінювання протипожежного стану об'єкта захисту - оцінювання об'єкта захисту щодо реалізації встановлених вимог пожежної безпеки, яке охоплює етапи обстеження та аналізування.

На основі аналізу чинних в Україні законодавчих та нормативно-правових актів щодо класифікації суб'єктів господарювання $[14,15]$ розроблено організаційну структуру СУПБ об'єкта захисту та встановлено наступне:

- діяльність із забезпечення пожежної безпеки, згідно $з$ [16], є складовою виробничої та іншої діяльності посадових осіб та інших осіб, які перебувають на об'єкті захисту;

- організаційна структура СУПБ повинна базуватися на наявній на об'єкті захисту організаційно-штатній структурі управління виробничою та іншою діяльністю; 
- на об'єкті захисту повинна створюватись відповідна організаційна структура СУПБ залежно від його особливостей щодо: існуючої організаційно-штатної структури управління виробничою та іншою діяльністю; функціонального призначення об'єкта; кількості осіб, які працюють та/або перебувають на об'єкті; категорій приміщень, будинків та зовнішніх установок за вибухопожежною та пожежною небезпекою; пожежної небезпеки технологічних процесів на об'єкті; пожежної небезпеки речовин та матеріалів, які використовують на об'єкті тощо.

Організаційна структура СУПБ об'єкта захисту в залежності від його особливостей може складатися 3:
- індивідуальних суб'єктів управління ПБ об'єкта захисту (власників або керівників суб'єктів господарювання, або орендарів об'єкта захисту, що визначено умовами договору оренди, або посадових осіб, призначених розпорядчим документом, які відповідають за певний напрям забезпечення пожежної безпеки об'єкта захисту);

- індивідуальних та колективних (колегіальних) суб'єктів управління ПБ об'єкта захисту (служби пожежної безпеки, комісії 3 питань надзвичайних ситуацій, підрозділів відомчої, місцевої або добровільної пожежної охорони).

Загальну схему організаційної структури системи управління пожежною безпекою об'єкта захисту наведено на рисунку 2.

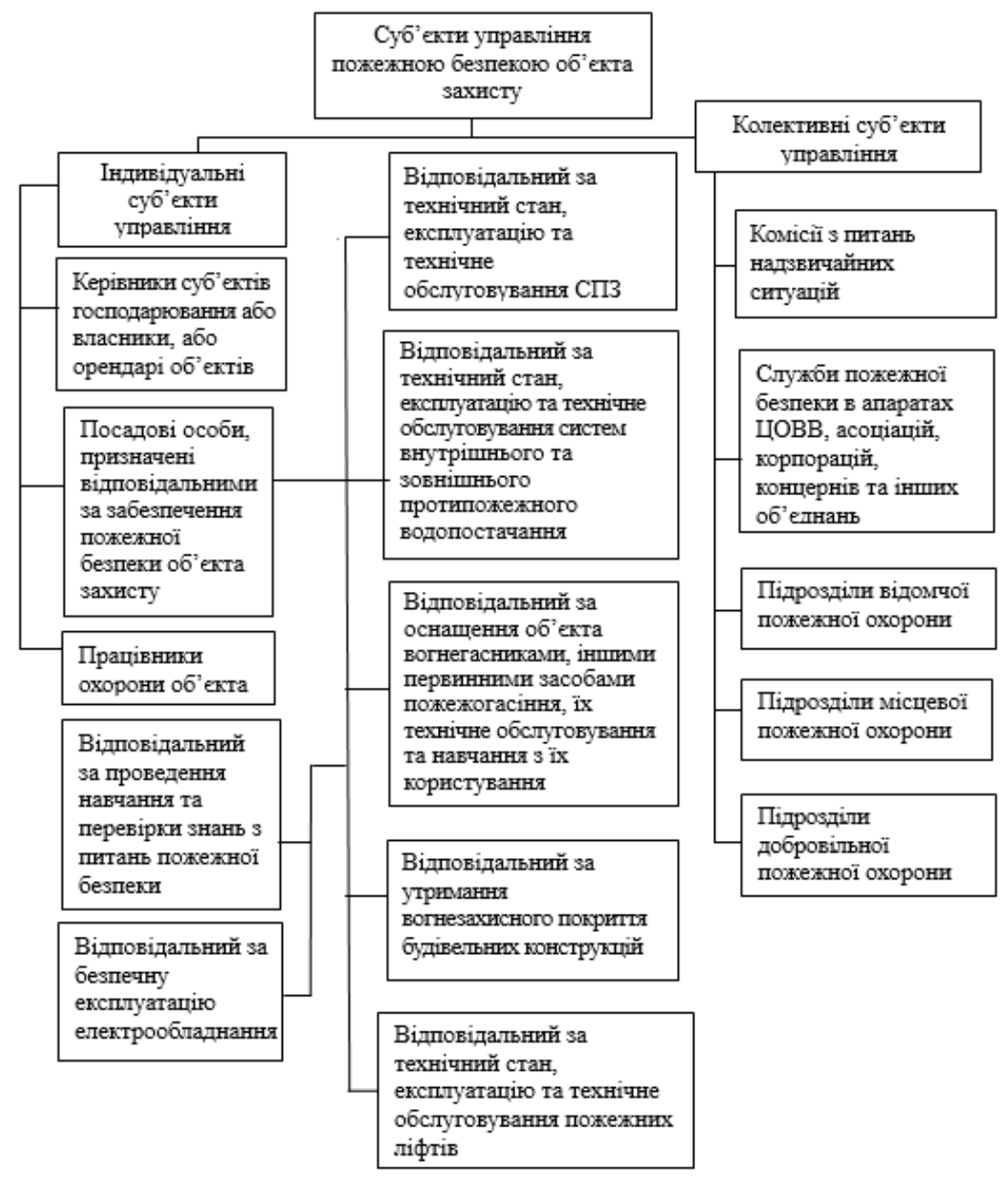

Рисунок 2 - Загальна схема організаційної структури СУПБ об'єкта захисту 
Крім того, СУПБ передбачає встановлення на об’єкті захисту відповідних правових та організаційних норм, а саме:

- рівнів відповідальності кожної посадової особи суб'єктів управління ПБ об'єкта захисту;

- розподілу обов'язків та повноважень між посадовими особами суб'єктів управління ПБ об'єкта захисту;

- забезпечення необхідного рівня компетенції та кваліфікації посадових осіб суб'єктів управління ПБ об'єкта захисту;

- визначення певного алгоритму управління (технології управління) ПБ об’єкта захисту, тобто забезпечення спільних дій структурних елементів СУПБ;

- забезпечення суб'єкта управління ПБ об'єкта захисту необхідними нормативними документами у сфері пожежної безпеки (стандартів, будівельних норм, інструкцій, положень, правил тощо) та розпорядчих документів.

- створення умов матеріального та морального стимулювання посадових осіб СУПБ для активізації їхньої діяльності та заохочення щодо забезпечення ПБ об’єкта захисту.

Функціювання СУПБ об'єкта захисту має бути забезпечене:

- формуванням організаційної структури СУПБ;

- обстеженням стану ПБ об'єкта захисту суб'єктом управління ПБ об'єкта захисту або суб'єктом господарювання, який одержав відповідну ліцензію;

- передаванням інформації щодо стану ПБ об'єкта захисту суб'єктом господарювання, який одержав відповідну ліцензію, суб'єкту управління ПБ, який приймає відповідні управлінські рішення;

- аналізуванням та оцінюванням протипожежного стану об'єкта захисту суб'єктом управління ПБ об'єкта захисту або суб'єктом господарювання, який одержав відповідну ліцензію;

- прийняттям суб'єктом управління ПБ об'єкта захисту відповідних управлінських рішень (заходів) та організацією фінансування заходів щодо забезпечення ПБ об'єкта захисту;

- здійсненням управлінського впливу суб'єкта управління ПБ об'єкта захисту на об'єкт управління, тобто організацією виконання запланованих управлінських рішень (заходів) щодо забезпечення ПБ об'єкта захисту, а також контролем за їхнім виконанням;
- здійсненням взаємодії суб'єкта управління ПБ об'єкта захисту з зовнішніми суб' єктами, що впливають на забезпечення ПБ цього об'єкта.

Загальну схему функціювання системи управління ПБ об’єкта захисту наведено на рисунку 3.

Обстеження стану ПБ об'єкта захисту (етап А, рисунок 3) щодо ідентифікації пожежних небезпек та можливості реалізації потенційних загроз виникнення та розвитку пожежі $\epsilon$ процесом отримання необхідної інформації для прийняття відповідних управлінських рішень.

Управління ПБ об'єкта захисту має здійснюватися за наявності повної, своєчасної й правдивої інформації про стан пожежної безпеки (етап Б, рисунок 3). Одержання такої інформації суб'єктом управління ПБ, виявлення відхилень від норм i правил пожежної безпеки, а також перевірка виконання попередніх планів, приписів i управлінських рішень здійснюються на основі регулярного та об’єктивного контролю.

Аналізування та оцінювання стану ПБ об'єкта (етап В, рисунок 3), у тому числі 3 оцінювання пожежного ризику, здійснюється на основі інформації, отриманої під час обстеження стану ПБ, а також іiі аналізування, шляхом визначення відповідності стану ПБ об'єкту вимогам нормативно-правових та нормативних документів у сфері пожежної безпеки.

На основі даних щодо оцінювання стану ПБ об'єкта захисту суб'єкт управління приймає управлінські рішення (етап $Г$, рисунок 3 ).

Наступним етапом процесу управління ПБ об'єкта захисту є здійснення суб' єктом управління ПБ управлінського впливу на об'єкт управління (етап Д, рисунок 3), тобто організація виконання запланованих управлінських рішень щодо забезпечення ПБ об'єкта захисту та контролювання їх виконання.

Організація виконання управлінських рішень щодо забезпечення ПБ об'єкта захисту здійснюється шляхом комунікації, тобто передачі інформації від суб'єкта управління до особи, яка повинна виконати це рішення.

Для ефективного функціонування системи управління ПБ об'єкту захисту має бути організована, на плановій основі, взаємодія 3 зовнішніми суб'єктами, що впливають на забезпечення ПБ об'єкту захисту (етапи Е та E1, рисунок 3). 


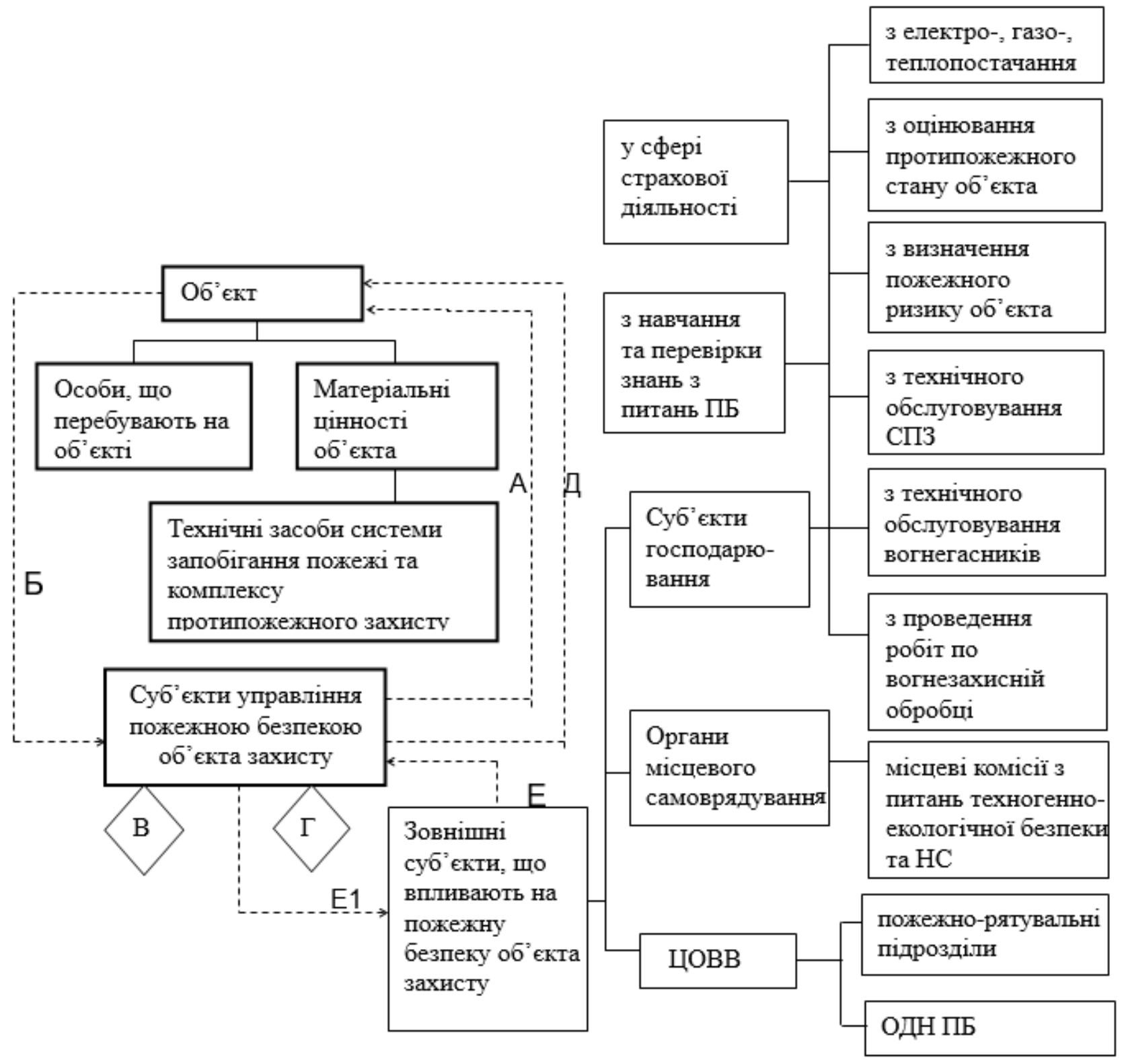

Умовні позначки:

етап А - обстеження протипожежного стану об'єкта захисту;

етап Б - передавання інформації суб'єкту управління щодо протипожежного стану об'єкта захисту;

етап В - аналізування та оцінювання протипожежного стану об'єкта захисту;

етап Г - прийняття управлінських рішень щодо забезпечення ПБ об'єкта захисту;

етап Д - організація виконання запланованих управлінських рішень щодо забезпечення ПБ об'єкта захисту та контролювання їх виконання;

етапи Е та Е1 - спільні дії із зовнішніми суб’єктами, що впливають на забезпечення ПБ об’єкта захисту

Рисунок 3 - Загальна схема функціонування СУПБ

Висновки. За результатами проведених досліджень сформульовані такі висновки:

1. На підставі аналізу статистичних даних про пожежі, їх причин та наслідки на підприємствах, організаціях і закладах визначено, що значною мірою вони пов'язані 3 недосконалою організаційно-управлінською діяльністю суб'єктів господарювання щодо забезпечення ПБ об'єкта.

2. Вперше встановлені терміни та визначення понять, які характеризують систему управління пожежною безпекою, а саме: суб'єкт управління пожежною безпекою об'єкта захисту, об'єкт управління пожежною безпекою об'єкта захисту, управління пожежною безпекою об'єкта захисту, оцінка протипожежного стану об'єкта захисту та управлінські заходи щодо забезпечення пожежної безпеки об'єкта захисту.

3. На основі аналізу законодавчих, нормативно-правових актів та нормативних документів, чинних в Україні, розроблено 
організаційну структуру системи управління пожежною безпекою об'єкта захисту, яка включає індивідуальні суб'єкти управління пожежною безпекою (власник об'єкта, керівники різних рівнів, посадові особи, призначені відповідальними за пожежну безпеку) та колективні суб'єкти управління (служби пожежної безпеки, місцеві комісії 3 питань надзвичайних ситуацій, підрозділи відомчої та добровільної пожежної охорони).

4. Визначено, що організаційна структура системи управління пожежної безпеки об'єкта захисту залежить від його особливостей, а саме: існуючої організаційно-штатної структури управління виробничою та іншою діяльністю об'єкта захисту, функціонального призначення об'єкта, кількості осіб, що працюють та/або перебувають на об'єкті, категорій приміщень, будинків та зовнішніх установок за вибухопожежною та пожежною

\section{СПИСОК ЛІТЕРАТУРИ}

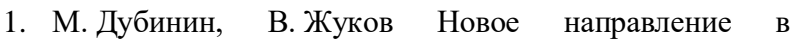
противопожарном нормировании. Чего не видит пожарная наука? // Алгоритм безопасности. - С.Петербург: № 4, 2014. - С. 94-97.

2. ГОСТ 12.1.004-91 ССБТ. Пожарная безопасность. Основные положения. - М.: ИПК Изд-во стандартов, 1996. $-86 \mathrm{c}$

3. Ніжник В.В., Сізіков О.О., Довгошеєва Н.М., Голікова С.Ю. Аналітичні дослідження щодо удосконалення системи запобігання пожежної безпеки об'єктів // Науковий вісник: Цивільний захист та пожежна безпека. - К.: № 1 (5), 2018. - С. 50-55.

4. Звіт про науково-дослідну роботу Провести дослідження та обгрунтувати загальні вимоги пожежної безпеки до об'єктів різного призначення. К.: УкрНДІЦЗ, 2017. - 565 с. - № РК 0117 U001199.

5. ДСТУ 8828-2019 Пожежна безпека. Загальні положення. - К.: УкрНДНЦ, 2019. - 151 с.

6. ДСТУ ISO 9000:2015 (ISO 9000:2015, IDT). Системи управління якістю. Основні положення та словник термінів. К.: УкрНДНЦ, 2016. - 51 с.

7. ДСТУ ISO 9001:2015 (ISO 9001:2015, IDT). Системи управління якістю. Вимоги. - К.: УкрНДНЦ, 2016. $32 \mathrm{c.}$

8. ДСТУ ISO 22000:2007 Системы управления безопасностью пищевых продуктов. Требования к небезпекою, пожежної небезпеки технологічних процесів на об'єкті, пожежної небезпеки речовин та матеріалів, що перебувають на об'єкті.

5. Систематизовано процес управління пожежною безпекою об'єкта захисту, встановлено вимоги до функціонування системи управління пожежною безпекою об'єкта захисту та розроблено відповідну схему функціонування СУПБ, тобто алгоритм управління, який передбачає етапи: обстеження протипожежного стану об'єкта захисту; передачу інформації щодо протипожежного стану об’єкта суб'єкту управління пожежною безпекою; аналізування та оцінювання протипожежного стану об'єкта захисту; прийняття управлінських рішень; організацію та контроль їх виконання; спільні дії із зовнішніми суб' єктами, що впливають на забезпечення ПБ об'єкта захисту.

любым организациям пищевой цепи (ISO 22000:2005, IDT) - К.: Держстандарт України, 2007. - 39 с.

9. ДСТУ ISO/IEC 27001:2015 Інформаційні технології. Методи захисту. Системи управління інформаційною безпекою. Вимоги (ISO/IEC 27001:2013; Cor 1:2014, IDT). - К.: УкрНДНЦ, 2016. - 22 с.

10. ДСТУ ISO 39001:2015 Системи управління безпекою дорожнього руху (БДР). Вимоги та настанова щодо застосування (ISO 39001:2012, IDT). - К.: УкрНДНЦ, 2016. $-36 \mathrm{c}$.

11. OHSAS 18001:2007 Occupational health and safety management systems - Requirement (Системы менеджмента охраны здоровья и обеспечения безопасности труда. Требования). [Електронний pecypc]. - Режим доступу: http://iso-management.com/ wp-content/uploads/2013/12/OHSAS-18001-2007-.pdf

12. НАПБ А.01.001-2014 Правила пожежної безпеки в Україні.

13. ДБН В.2.5-56:2014 Системи протипожежного захисту. - К.: Мінрегіон України, 2015. - 133 с.

14. Господарчий Кодекс України [Електронний ресурс]. Режим доступу: https://zakon.rada.gov.ua

15. Цивільний Кодекс України [Електронний ресурс]. Режим доступу: https://zakon.rada.gov.ua

16. Кодекс цивільного захисту України [Електронний pecypc]. - Режим доступу: https://zakon.rada.gov.ua 


\section{REFERENCES}

1. M. Dubinin, V. Zhukov Novoe napravlenie v protivopozharnom normirovanii. Chego ne vidit pozharnaja nauka? // Algoritm bezopasnosti. - S.Peterburg: № 4, 2014. - S. 94-97.

2. GOST 12.1.004-91 SSBT. Pozharnaja bezopasnost'. Osnovnye polozhenija. - M.: IPK Izd-vo standartov, 1996. $-86 \mathrm{~s}$.

3. Nizhnik V.V., Sizikov O.O., Dovgosheєva N.M.,Golikova S.Ju. Analitichni doslidzhennja shhodo udoskonalennja sistemi zapobigannja pozhezhnoï bezpeki ob'ektiv // Naukovij visnik: Civil'nij zahist ta pozhezhna bezpeka. K.: № 1 (5), 2018. - S. 50-55.

4. Zvit pro naukovo-doslidnu robotu Provesti doslidzhennja ta obrruntuvati zagal'ni vimogi pozhezhnoï bezpeki do ob'ektiv riznogo priznachennja. - K.: UkrNDICZ, 2017. 565 s. - № RK 0117 U001199.

5. DSTU 8828-2019 Pozhezhna bezpeka. Zagal'ni polozhennja. - K.: UkrNDNC, 2019. - $151 \mathrm{~s}$.

6. DSTU ISO 9000:2015 (ISO 9000:2015, IDT). Sistemi upravlinnja jakistju. Osnovni polozhennja ta slovnik terminiv. K.: UkrNDNC, 2016. - $51 \mathrm{~s}$.

7. DSTU ISO 9001:2015 (ISO 9001:2015, IDT). Sistemi upravlinnja jakistju. Vimogi. - K.: UkrNDNC, 2016. - 32 S.

17.
8. DSTU ISO 22000:2007 Sistemy upravlenija bezopasnost'ju pishhevyh produktov. Trebovanija $\mathrm{k}$ ljubym organizacijam pishhevoj cepi (ISO 22000:2005, IDT) - K.: Derzhstandart Ukraïni, 2007. - $39 \mathrm{~s}$.

9. DSTU ISO/IES 27001:2015 Informacijni tehnologii. Metodi zahistu. Sistemi upravlinnja informacijnoju bezpekoju. Vimogi (ISO/IEC 27001:2013; Cor 1:2014, IDT). - K.: UkrNDNC, 2016. - $22 \mathrm{~s}$.

10. DSTU ISO 39001:2015 Sistemi upravlinnja bezpekoju dorozhn'ogo ruhu (BDR). Vimogi ta nastanova shhodo zastosuvannja (ISO 39001:2012, IDT). - K.: UkrNDNC, 2016. - $36 \mathrm{~s}$.

11. OHSAS 18001:2007 Occupational health and safety management systems - Requirement. URL: http://isomanagement.com/wp-content/uploads/2013/12/OHSAS18001-2007-.pdf

12. NAPB A.01.001-2014 Pravila pozhezhnoï bezpeki v Ukraïni.

13. DBN V.2.5-56:2014 Sistemi protipozhezhnogo zahistu. K.: Minregion Ukraïni, 2015. - 133 s.

14. Gospodarchij Kodeks Ukraïni URL: https://zakon.rada.gov.ua

15. Civil'nij Kodeks Ukraïni [Elektronnij resurs]. - URL: https://zakon.rada.gov.ua

16. 16. Kodeks civil'nogo zahistu Ukraïni URL: https://zakon.rada.gov.ua 


\section{SYSTEMATISATION OF THE MANAGEMENT PROCESS OF FIRE SAFETY FOR PROTECTED OBJECT}

O. Sizikov, Cand. Of Sc. (Eng.), V. Nizhnyk Cand. Of Sc. (Eng.), Y. Ballo, Cand. Of Sc. (Eng.), S. Golikova, O. Savchenko

The Ukrainian Civil Protection Research Institute, Ukraine

\section{KEYWORDS}

the facility's fire safety management system, organizational and management measures, the entity of fire safety management, the facility management, the organizational structure, control algorithm

ANNOTATION

Results of researches are resulted as substantiation of the general provisions of the fire protection management system of the object of protection. For the first time, a series of terms and definitions have been developed to characterize and specify the individual elements of the facility's fire safety management system. Imperfection of existing approaches to existing organizational measures of fire safety at the object of protection is shown. Shown national and international experience in effective sales management influence management decisions using business management object protection that allows realizing on objects of different functions organizational requirements and technical requirements for fire prevention systems and complex fire protection. Studies of domestic and foreign studies have shown that effective management influence with the help of management decisions of the subjects of management allows to effectively implementing on the objects the technical requirements of the fire prevention system and fire protection system. The experience gained in the organization of the management system, the management decisions and the provisions for ensuring the fire safety of the object of protection should be systematized, and the algorithm for managing this process should be standardized. As a result of the conducted researches the organizational structure of the fire safety management system of the object was developed and requirements for its operation and control algorithm. The result of the work is the draft standard "Fire Safety Management System of the Object of Protection. General Provisions", which is to be approved by the order of the National standardization body of Ukraine and subsequently used by the central executive bodies, local self-government bodies, economic entities and bodies and units of the State Emergency Service of Ukraine.

\section{СИСТЕМАТИЗАЦИЯ ПРОЦЕССА УПРАВЛЕНИЯ ПОЖАРНОЙ БЕЗОПАСНОСТЬЮ ОБЪЕКТА ЗАЩИТЫ}

А.А. Сизиков, канд. техн. наук, ст. науч. сотр., В.В. Нижник, канд. техн. наук, ст. науч. сотр., Я.В. Балло, канд. техн. наук, С.Ю. Голикова, О.В. Савченко

Украинский научно-исследовательский институт гражданской защиты, Украина

\section{КЛЮЧЕВЫЕ СЛОВА}

система управления пожарной

безопасностью объекта,

организационно-управленческие

мероприятия, субъект управления

пожарной безопасностью объекта

защиты, объект управления,

организационная структура, алгоритм

управления

\begin{abstract}
АННОТАЦИЯ
Приведенные результаты исследований по обоснованию общих положений системы управления пожарной безопасностью объекта защиты. Впервые установлен ряд терминов и определений понятий, характеризующих и конкретизирующих отдельные элементы системы управления пожарной безопасностью объекта. Показано несовершенство существующих подходов относительно существующих организационных мер обеспечения пожарной безопасности на объекте защиты. Приведены отечественный и зарубежный опыт по эффективной реализации управленческого воздействия с помощью управленческих решений субъектов управления объекта защиты, что позволяет реализовывать на объектах различного функционального назначения организационные и технические требования к системе предотвращения пожара и комплекса противопожарной защиты. В результате проведенных исследований разработана организационная структура системы управления пожарной безопасностью объекта и установленные требования по ее функционированию и алгоритму управления
\end{abstract}

